Uniwersytet Jagielloński

Wydział Studiów Międzynarodowych i Politycznych

Katedra Ukrainoznawstwa

tel. + 48126341680

e-mail: alicja.z.nowak@uj.edu.pl

\title{
O grzechu pijaństwa w ruskich naukach dla kapłanów (metropolia kijowska od XI do pocz. XVIII w.)
}

Słowa kluczowe: pijaństwo, grzech, kapłan, nauka

W jednej z najstarszych znanych drukowanych ruskich nauk dotyczących sakramentów (Wilno ok. 1617/1618), w dziele o pokucie czytamy, że grzechy główne to te, z których niczym z „korzenia” wyrastają pozostałe przewinienia: „А и(ж) з грб̆ховъ седми помененыхъ, яко з тыхъ которые суть головными на(з)ваные, вси иные грбххи, такь власне яко о(т) корени в бтвїе походя(т)" [Наука, 54 $]^{1}$. W podobny sposób definiowały grzech główny - przyczynę pobudzającą do rozmaitych wykroczeń, katolickie (w tym także bazyliańskie) [Derdziuk 1996, 155]² oraz prawosławne źródła.

XVII w. moraliści wskazywali nieumiarkowanie w jedzeniu i piciu jako źródło wielu groźnych dla duszy grzechów. Innocenty Gizel określał te grzechy „owocami, a autor Nauki o sakramencie pokuty - „córkami obżarstwa”. Stosując różne wersje językowe wskazywali następujące pochodne omawianego grzechu: przytępienie umysłowe (притупленїе рузума, помраченіе

\footnotetext{
1 Na temat rozbieżności w datowaniu, ustaleniu autorstwa i wydawcy tej nauki por. М. Корзо [2014, 90-91].

2 Obżarstwo i nieumiarkowanie w piciu było nazywane grzechem głównym, przeciw cnocie kardynalnej umiarkowania/trzeźwości [Derdziuk 1996, 165].
} 
ума), bezmyślną wesołość (безчинноє веселїе, прожная радость), wielomówstwo (многоглаголанїе, велемовство), błazenadę (безчинноє кощунство, жартыл), cielesną nieczystość (тплесное оскверненїе, роспаленїе на вшетеченство, нечьстость коли который есть албо пье (m) ажъ до скине $(н) я)$, lenistwo i opieszałość (лпнивство, нераденіє)" [Гізіель 2009, 157-158; (Гізіель) 2012, 506-507; Наука ok. 1617/1618, 56]³.

Pierwsze systematyczne próby kategoryzacji grzechów na gruncie prawosławnej kultury w Rzeczypospolitej podjęto pod wpływem chrześcijańskiego Zachodu w dobie odrodzenia cerkiewnego. Jednym z najwcześniejszych przykładów takiego ujęcia w tekstach wydanych drukiem może posłużyć cytowana wyżej wileńska nauka oraz wstęp do Nomokanonu kijowskiego z 1629 r., w którym metropolita kijowski Piotr Mohyła wprowadził rozróżnienie grzechów uczynkowych m.in. na duchowe i cielesne, które czynią nieczystym ciało, tak jak w przypadku pijaństwa [Могила 1989, 9] ${ }^{4}$. Wedle zaproponowanych w przedmowie innych definicji jest ono również grzechem „zewnętrznym”, bowiem do tej kategorii należą uczynki sprzeciwiające się prawu i woli Bożej, jawne, niosące zgorszenie i w konsekwencji powodujące upadek w grzech drugiego człowieka. Jest to też według innego zaszeregowania tzw. grzech „własny”, gdyż sami grzeszymy i „cudzy” ponieważ nie przeciwstawiamy się grzechowi bliźniego [Могила 1989, 9]. Są to charakterystyki szczególnie celnie opisujące rozmiar spustoszeń, które czyni opilstwo, jeśli dotyczy kapłana - sługi ołtarza i słowa.

W XVII w. wieku powstały również pierwsze uwzględniające tę systematyzację katechizmy. Wzorem katolickich prac grzechy dzielono w nich na śmiertelne i powszednie, obżarstwo, a zatem także pijaństwo, jako jeden z siedmiu grzechów głównych należało do tej pierwszej kategorii [Могила 1898, 457-458]. W miarę rozwoju teologii moralnej pojawiły się poradniki dla spowiedników, zalecające, by ocena sumień przebiegała nie tylko według list zaszeregowujących dany grzech, ale i z uwzględnieniem czynni-

$3 \mathrm{~W}$ wielu katolickich, w tym bazyliańskich podręcznikach, opis konsekwencji tego grzechu jest zbliżony, zgadza się również liczba wspomnianych „owoców”: „tępota umysłu, i niesposobność do modlitwy i nauki, płocha wesołość skłaniająca do nieprzystojnych żartów i śpiewów, wielomówstwo używające niepotrzebnych słów, błazeństwo, czyli zachowanie powodujące śmieszność i wzbudzające litość, oraz zachowania nieprzystojne w postaci wymiotów i aktów nieczystości" [Derdziuk 1996, 167]. Badacz omawia, co prawda prace teologów osiemnastowiecznych, ale powyższe schematy musiałyby być sformowane już w poprzednim stuleciach, a zatem moraliści katoliccy i prawosławni czerpali z podobnych źródeł; O katolickich źródłach zapożyczeń w traktacie Gizela, por. M.A. Kорзо [2010, 167-262].

4 Mohyła wyszczególniał grzechy śmiertelne i uczynkowe, ale dzielił je także według innych kryteriów m.in. na uczynione z woli, i bez woli, przeciw sumieniu itd. 
ków, takich jak np. okoliczności popełnienia czynu. W ten sposób ustalano prawdziwą rangę i „ciężar” grzechów ${ }^{5}$. Jednym z takich istotnych czynników wpływających na range grzechu był status osoby popełniającej dany czyn. W Nauce czytamy np. że ten sam grzech popełniony przez osobę duchowną jest znacznie cięższy niż w przypadku osoby świeckiej: „Особа которая греши(т), если бовемъ есть духовная албо законная, тогды болей грешы(т), ни(ж) свецкая, и тымъ еще болшъ, и(м) в болшомъ есть степени пос(ве)щенїя, хочь бы грехъ обадва един пополнили" [Наука ok. 1617/1618, 60].

Najwięcej uwagi poświęcił temu problemowi Innocenty Gizel w części hamartiologicznej obszernego i zarazem pierwszego w kulturze ukraińskiej traktatu dotyczącego teologii moralnej. W Pokoju z Bogiem człowiekowi dzielił obżarstwo (чре̃воугодie) na dwie odmiany: objadanie (обяденіе) i opilstwo (піянство)" [Гізіель 2009, 154]. Podobnie jak katoliccy moraliści uznawał, że dobrowolne i świadome pozbawienie się rozumu z użyciem alkoholu jest grzechem śmiertelnym [Derdziuk 1996, 165; Гізіель 2009, 270]. Wymienił jednak również czynniki powodujące, że pijaństwo można było zaszeregować do grzechów powszednich. Miało to miejsce wówczas, gdy człowiek nie tracił w zupełności władzy nad umysłem, upił się, jak niegdyś Noe, nie znając wcześniej skutków tego czynu, lub zastosował alkohol w celach kuracyjnych, nie znając innego sposobu na poratowanie zdrowia [Гізіель 2009, 155-156]. Zasada obowiązywała wszakże pod warunkiem, że człowiek nie popełnił pod wpływem trunku innych śmiertelnych grzechów. Zdaniem kijowskiego teologa grzechy wcześniej nieplanowane czy spodziewane, np. zabójstwo, które popełniono w wyniku pijatyki, nie powinno być przez spowiednika uważane za osobny grzech w sumieniu (abstrahując od odpowiedzialności prawnej). Jeśli jednak ktoś jest świadom zmian w osobowości, które następują w nim w wyniku spożycia alkoholu, to wówczas okoliczność łagodząca nie występuje, będzie za czyn sądzony osobno, taka pijatyka bowiem „грђххомъ єстъ смертнымъ по писанному: Пїаници

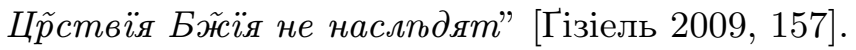

\footnotetext{
5 Intuicja spowiednicza $\mathrm{w}$ tym zakresie wyprzedziła oficjalne ustalenia w dziełach teologicznych czy zarządzeniach dyscyplinarnych, czego świadectwem są pisma Ojców Kościoła, ustalenia soborów. Np. Jan Chryzostom stwierdził, że rozumienie istoty zła i zarazem jego czynienie zwiększa winę grzesznika, por. np. [Иже въ ст̃ ыъъ 1614, 207-308]; por. także 102 kanon in Trullo, [Kanony 2000, 107]. Przykładem z ruskiego gruntu może posłużyć komentarz metropolity Cypriana (XIV w.), który pisząc o pewnym grzechu, twierdził, że ten sam grzech popełniony z niedbalstwa jest cięższy niż z braku wiedzy, por. Митр. Кипріан [1861, 136-137].
} 
Tak szczegółowe opisy grzechów i ich systematyczna selekcja: podział na grupy i kategorie, szczegółowe definicje z użyciem odpowiedniej terminologii, pojawiły się w drukowanych źródłach w metropolii kijowskiej dopiero w XVII w. pod wpływem teologii moralnej zachodniej, bowiem tam stała się ona osobną dziedziną teologii w XVI w. Niemniej jednak sam problem pijaństwa jest ponadczasowy, a sposób, w jaki ujmowali kwestie hamartiologiczne nauczyciele czasów Rusi Kijowskiej był w istocie zbliżony. Działo się tak dlatego, że podobne skutki nadmiernego spożywania pokarmów i trunków wskazywali apostołowie i Ojcowie Kościoła, a wśród nich Jan Klimak (VII w.) - synajski opat. Jego popularna na Rusi Lestwica czyli Drabina do raju ${ }^{6}$ [Thomson 1999, 112-113] w sekcji poświęconej walce z grzechem nieumiarkowania $\mathrm{w}$ jedzeniu i piciu zawiera tezę, że obżarstwo stanowi przyczynę wszelkich upadków i naruszeń dyscypliny życia mniszego, nazywa je „bramą namiętności” wiodącą do wielu grzechów. Przytoczona lista przewinień zapewne była źródłem inspiracji dla późniejszych twórców:

Moim pierworodnym synem [obżarstwa] jest przydatna rozpusta, a drugim zatwardziałość serca, trzecim sen: morze myśli, fale brudu. Pochodzi ze mnie otchłań niepoznawalnych i niewysłowionych nieczystości. Moimi córkami są opieszałość, wielomówstwo, rozwiązłość języka, kpiarstwo, błazeństwo, spór, krnąbrne nieposłuszeństwo, niewrażliwość, zniewolenie, chełpliwość, zuchwalstwo, upodobanie w świecie, a za nimi następują splugawiona modlitwa i niepokój myśli. Często też niespodziewane i nagle nieszczęśliwe zdarzenia, a z nimi obcuje beznadzieja, bardziej od nich wszystkich niebezpieczna. Walczy ze mną i nie ustępuje mi pamięć o upadkach; zawsze mnie nienawidzi myślenie o śmierci; ale bezwzględnie mnie zniweczyć nie może żaden z ludzi [Klimak 2011, 198; Patrologia vol. 88, 869D].

Warto podkreślić, że stanowiąca podstawę doktryny o siedmiu grzechach głównych lista ośmiu ciężkich przewinień powstała przy sporym udziale Wschodnich Ojców Kościoła ${ }^{7}$. Uważa się, że największy wkład w uporządkowanie listy najcięższy grzechów mieli Orygenes oraz Ewagriusz z Pontu (IV w.), który podsumował doświadczenia ascetyczne egipskich mnichów i wyszczególniając osiem głównych, złych myśli. W dziele O praktyce [ascetycznej] wymieniał kolejno: obżarstwo, nieczystość, chciwość, smutek, gniew, acedię (czyli obojętność, zniechęcenie, lenistwo), próżną chwałę i pychę [Špidlik 2005, 317]. Zdaniem J. Delumeau ta klasyfikacja jest w za-

6 W Bułgarii i Serbii dzieło było tłumaczone w X-XI w., na Rusi najstarszy jego odpis pochodzi z XII w., choć cytowane było już w XI w. np. w Izborniku Światosława, na ten temat por. A. Jasiewicz [2011, 83-85]; por. także Перекладна [2014, 187].

7 Byli to m.in. autor Didache, Tertulian, św. Cyprian, św. Grzegorz, por. J. Delumeau [1994, 276]. 
mierzeniu hierarchiczna i wskazuje porządek w jakim należy zwalczać złe skłonności [1994, 276-277]. Listę rozpropagował na Wschodzie Jan Klimak we wspomnianym dziele, zaś na Zachodzie Jan Kasjan (V w.) i Grzegorz Wielki (VI-VII w.) $)^{8}$.

Problem z opilstwem znalazł swoje odzwierciedlenie w najstarszych zabytkach Rusi Kijowskiej, w których z niemniejszym zaangażowaniem niż w stuleciach późniejszych wskazywano następstwa popełniania tego grzechu. I tak w Izborniku Światosława z 1073 r. córkami pijaństwa nazwano rozpustę, zawiść i bałwochwalstwo ${ }^{9}$, a w wersji zabytku z 1076 r. chmiel i inne trunki były wskazywane jako źródło męskich namiętności ${ }^{10}$. W osobnej sekcji dzieła zatytułowanej $O$ Miodzie, czytamy, że nadmierne spożycie alkoholu wywołuje duchowe zgorzknienie, wzbudzony zostaje gniew i skłonność do obmowy [Золоте 2002a, 402]. W tym samym stuleciu metropolita kijowski Jan II sformułował dyscyplinarne zasady, jedna z nich, 29. o grzesznych skutkach pijaństwa, również zawiera omówienie pochodnych opilstwa: „,...] пьянство много зла посльдуєтъ: невздержаньє, нечистота, блудъ, хуленьє,

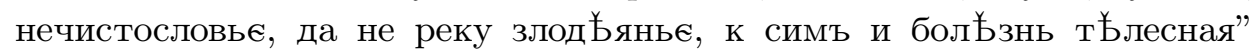
[Іоана 1880, kol. 17]. Bardzo szczegółową listę wykroczeń wywołanych nadmiernym spożyciem alkoholu skomponował biskup Grzegorz (XII w.). Znalazły się na niej m.in. zazdrość, oszustwo, kradzież, zawiść, gniew, a nawet skłonność do donoszenia:

Коли ви уп'єтеся, тоді ви блудите і стрибаєте, кричите, співаєте й танцюєте, і в дудки дудите, заздрите, п'єте засвіта, об'їдаєтеся й упиваєтеся, блюєте і обманюєте, злопам'ятствуєте, гніваєтеся, лаєтеся, хулите і сердитесь, море вам по коліна, смієтеся, крадете, б'єтеся і чините марнослів'я, про смерт не пам'ятаєте, спите багато, звинувачуєте і засуджуєте, божитеся і докоряєте, доносите... [Повчання мудрого 2002, 178 $]^{11}$.

\footnotetext{
8 Za ich sprawą w VI-VII w. lista została skrócona do siedmiu pozycji, bowiem pycha i próżna chwała zostały połączone w jeden grzech i znalazły się na czele listy. Papież zamienił acedię zazdrościa, a w obręb smutku włączył duchowe lenistwo [Delumeau 1994, 277]; Takie zestawienie siedmiu grzechów było znane na całym Zachodzie w XIII w. Na Wschodzie zazdrość zamieniła smutek, jako jego odmiana wywołana przez dobro, które spotyka innych ludzi [Špidlik 2005, 318-319].

9 Wypisy z tekstu por. hasło: блудъ [Срезневский 1893, 117].

10 Por. np. „ДҺлятель пияница не обогатъєть”, „Медъ и жены отворять разоумьныя...”, „ББгай пияньства и отъ печалии жития сего [...]”, „Паче же вьсего достоить чл̃коу въздрьжати ся отъ бесђ̆дъ женскыхъ и срамьныхъ словесъ, медъ бо и жены отъвраштяютъ и съмысльныя", суt. zа: Золоте [2002а; 392, 416, 417].

11 Spis wykroczeń jest podobny do katolickich zestawień opisanych przez A. Derdziuka, ale od nich bogatszy, por. cytat w przypisie 3 .
} 
Adresatem licznych przestróg przed pijaństwem było duchowieństwo. Przykładowo do Izbornika Światosława (1076 r.) włączono Pouczenie dla kapłanów przypisywane Janowi Złotoustemu o incipicie „Паки же ты презвитер Христов...”. Spożywanie alkoholu zostało w nim potraktowane jako profanacja modlitwy i pozostawało, zdaniem autora nauki, w rażącej sprzeczności z powołaniem kapłana - ziemskiego anioła [Іоанн Златоуст 2002a, 411, 413] ${ }^{12}$. Kazanie prawdopodobnie uznawano za wartościowe źródło wiedzy dla jerejów i dlatego zostało umieszczone również w składzie Ksiegi Kormczej ${ }^{13}$. Wydrukowano je w nieco odmiennej wersji językowej w 1712 r. w składzie pracy Dialogizm duchowy w sporej części poświęconej posłudze ołtarza. Autor dzieła Warłaama Golenkowski uczynił zeń przedmowę dzieła i nawołując słowami Chryzostoma kapłanów - „cielesnych serafinów" do cnotliwego życia i wystrzegania się wymienionych grzechów, szczególny akcent postawił na problemie pijaństwa: „[...] служителю Хр̃стовъ хранися от питїя, серафімъ бо єси плотяный, и нелН̆пно ти єсть прилђжати питїю, к сему же єще и любоимбнїю, гордости, осужденїю, славохотїю, и гнђву и блудным помышленїамъ" [Голенковский 1714,5$]$.

Napomnienia dotyczące nieumiarkowania w jedzeniu i piciu, a także nieprzystojnych gier i zabaw stanowiły stałe miejsce pouczeń w czasach średniowiecza. Wymienione grzechy popełniane przez nie w pełni schrystianizowanych wiernych, ale także przez osoby duchowne były przedmiotem troski kościelnych hierarchów żyjących w pierwszych stuleciach po przyjęciu chrześcijaństwa [Podskalsky 2000, 265]. Dlatego problem pijaństwa był omawiany przez większość staroruskich kaznodziejów piętnujących pogańskie relikty ${ }^{14}$.

Przykładem służy bardzo popularna przez wiele stuleci egzorta przypisywana Teodozemu Pieczerskiemu, a także Janowi Złotoustemu zatytułowana, jako napomnienie lub pouczenie do syna duchowego. Niemal w całości wypełniała ją lista duchowych i materialnych spustoszeń, które są wynikiem nadużywania alkoholu ${ }^{15}$. Z imieniem świętego pieczarnika związane są

$12 \mathrm{~W}$ antologii znajduje się tekst oryginału wraz z równoległym tłumaczeniem na jęz. ukr.

13 Przykładowo występuje ono z tytułem Іоанна Златоустаго наказанїе всякому попови, m.in. w składzie rękopiśmiennego Nomokanonu z XVII w. (I ćwierćwiecze), na kartach 399v-400v, por. Biblioteka Narodowa (Akc 2736, mf 15349). Jest także w: Kormczej z końca XVI w. (k. 414v-415v), por. [Кириличні 2007, 264, nr 202]; w Kormczej (XV w.) z Biblioteki Jagiellońskiej (Akc 71/1952) na s. 360-361, por. Я.Н. Щапов [1976, 147].

14 Badacz zauważył, że podejmowane były próby układania antologii tekstów staroruskich pod kątem tematycznym, np. o zwyczajach pogańskich, przykłady por. [Podskalsky 2000, 357, przypis 1149].

15 Pouczenie zachowało się w jednej z redakcji Szmaragdu i w Złatouście. W tym pierw- 
także: Pouczenie o karach Bożych, którego część pierwsza dotyczyła pogańskich zabobonów: kuglarzy, gry na gęślach i obchodzenia rusalii16, a druga - pijaństwa oraz Pouczenie św. Pankracego, w którym w ostrych słowach piętnowane są skutki opilstwa [Podskalsky 2000, 135-136]. W kolejnym stuleciu problem stał się przedmiotem rozważań białogrodzkiego biskupa Grzegorza (1186-1193). Jego pouczenie w całości skupione było na pijaństwie, które musiało dotyczyć szerokiego kręgu odbiorców, skoro pierwsze słowa władyka skierował do: mężczyzn i kobiet, osób świeckich i duchownych: mnichów, popów; a także do biednych i bogatych mieszkańców Rusi, tak stałych, jak i cudzoziemców ${ }^{17}$. Podobnie jak autor kazania o Karach Bożych przypominał on młodym chrześcijanom, że trunki Bóg podarował ludziom dla radości, nie pijatyki.

Припиніть, брати, прокляту пиятику, бо на рардість нам дав Бог трунки, а також у потрібний час, а не на пиятику [Повчання мудрого 2002, 178].

,,[... ино бо піанство есть злое, а ино питье в мђру, и в законь, и в подобно время, и въ славу Божію [O казняхъ 1973, 86].

Obaj moraliści nawoływali do zarzucenia alkoholu w święta, kiedy to należy głosić chwałę Bożą modlitwą i trzeźwym umysłem, nie zaś oddawać duszę diabłu.

I кажете: Тоді тільки свято гарне, якщо на кілька днів ми нап'ємося! Подумайте самі, що кажете: адже, відволікаючись від свята, дияволу ви догоджаєте! Як зачерствив сатана вашу душу! Але для чого так багато я говорю? Розкайтеся! Відмовитеся від таких веселощві, що велять напиватися на свята, і заплачте, каючись за ваші надмірности, бо закриєтся царство небесне [Повчання мудрого 2002, 178].

На праздники же великіа пировъ не творити, піанства бЊгати, испити мало и блюсти душа своа, и стеречи часа, в онъже Богу молитися трезвымъ умомъ, а не пьянимъ, якоже Петрь Апостоль рече: братія, будите трезви, якоже супостатъ вашь діаволъ ищеть піаныхъ, да я пожретъ [О казняхъ 1973, 85].

szym zbiorze z tytułem: Посланіе нпкоєго отиа къ сыну духовному (отъ словесъ Іоанна Златоуста), w drugim: Въ среду сыропустныя недпли поученіе отца духовнаго къ сыну духовному. Fragmenty tego napomnienia stały się także częścią innych znanych tekstów dotyczących problemu, więcej na ten temat por. С.И. Смирнов [1898, 2-4].

16 Tekst pouczenia $O$ казняхъ Божіuхъ będziemy cytować z wersji zachowanej w Toríestwienniku (Muzeum Rumiancewa) przedrukowanej w drugim wydaniu pracy: Я. Левицький [1973, 83-86]; Pierwsza część pouczenia została niedawno wydana w wersji ukraińskojęzycznej: [Про кари 2002a, 321-323].

17 Biskup wylicza adresatów w pierwszych słowach kazania. Tekst w tłumaczeniu na współczesny język ukraiński por. [Повчання мудрого 2002, 176-178]. 
W XII wieku powstało również pouczenie o nadmiernej pijatyce. Miało ono należeć pióru ihumena nowogrodzkiego Mojżesza, który uczył umiarkowania w korzystaniu z Bożych dobrodziejstw: snu, pożywienia, napojów i zawstydzał człowieka porównując go do zwierzęcia częstokroć rozumniejszego w dozowaniu owych przyjemności18.

W okresie Rusi Kijowskiej znanych było także wiele nauk przypisywanych Ojcom Kościoła. Te przypisywane Janowi Złotoustemu zostały omówione wyżej, inne dwa kazania pseudo-Bazylego również dotyczyły opilstwa. Jedno z nich przedstawiało objawienie Bogurodzicy, której Bazyli miał złożyć obietnicę wstrzemięźliwości od alkoholu, gdyż ten rujnuje ciało, godność, szczęście i nadzieję na zbawienie [Podskalsky 2000, 360]. Drugie kazanie wyznaczało miarę trzech kielichów wina dla chrześcijanina, siódmy, według moralisty, wywoływał gniew Boży, ponieważ otumaniony alkoholem człowiek tracił nad swym ciałem i duchem panowanie, tym samym władzę przekazując szatanowi, i stając się zdolnym do czynów haniebnych (kazirodztwo, morderstwo). Pouczenie zawiera także przestrogi przed profanowaniem modlitwy i zakaz śpiewania pieśni kościelnych (troparionów) jak biesiadnych poza świątynią i w stanie po spożyciu alkoholu [Podskalsky 2000, 359] ${ }^{19}$.

Szczegółową listę ciężkich grzechów, w tym nieumiarkowania w piciu zawieraja także trzynastowieczne kazania Serapiona biskupa Włodziemierza $^{20}$. W skład Nomokanonu niekiedy wchodziły czternastowieczne pouczenia metropolity Piotra Rateńskiego. Także on przestrzegał przed pijaństwem i udziałem w biesiadach osoby duchowne i ludzi świeckich. Ponadto kapłanom przypominał zakaz spożywania wina przy posiłku w szatach liturgicznych:

[...] пьянства лишайтеся и лишнехъ пиров, коли бываєть гов Ййн, тогда бы лишнихъ пировъ не было, а вы, священныи чинъ в Һ̌ка сего, лишайтеся пьянства въ гов йно, а который священникъ учнетъ пити до объда, ино быти єму без ризъ, да предстоитъ въ церкви ко всякому правилу церковному [Поученіе смиренного 1862, 186].

Wiele pouczeń i dokumentów kościelnych dotyczących pijaństwa kierowano bezpośrednio do przedstawicieli stanu duchownego. Kwestia mo-

18 Na temat problemów z atrybucją obu dwunastowiecznych tekstów (Grzegorza i Mojżesza) i o dostępnych wydaniach pisze G. Podskalsky [2000, 349-350]; Tekst w tłumaczeniu na współczesny język ukraiński por. Повчання Мойсея [2002, 175].

19 Podskalsky pisze, że to pouczenie uchodziło niegdyś za utwór Teodozjusza Pieczerskiego, por. [2000, 360 przyp. 1156].

20 Tekst pięciu kazań Serapiona wydał wraz z opracowaniem E. Пちँтухов [1888]. Krótki komentarz do kazań, por. [Podskalsky 2000, 153]. 
ralności kleru była regulowana prawem kościelnym, a hierarchowie młodej wspólnoty chrześcijańskiej na Rusi reagowali na nadużycia w tym obszarze: poddając je dyskusji synodalnej i opracowując zarządzenia $\mathrm{w}$ formie obowiązujaccych dyscyplinarnych zasad.

Pierwszym zabytkiem o charakterze kanonicznym na Rusi były Reguty metropolity Jana II (1080-1089). Trzynaście spośród trzydziestu czterech zasad dotyczyło hierarchów, duchowieństwa świeckiego i mnichów, ich praw, obowiązków i sposobu życia. Trzy zasady $(24 ., 29$., 34.) skupione były wyłącznie na grzechu obżarstwa, pijaństwa i ucztowania ze śpiewem i grami [Іоана 1880, kol. 13-14, 16-18, 20] ${ }^{21}$. Ten zabytek szybko stał się częścią Ksiegi Kormczej, tym samy zyskując autorytet prawny, kanoniczny dla Kościoła na Rusi [Podskalsky 2000, 265, przyp. 810] $]^{22}$.

Zachowała się także dwunastowieczna mowa nowogrodzkiego arcybiskupa Eliasza zawierająca m.in. dyscyplinarny nakaz kapłańskiej trzeźwości, co zostało omówione w kontekście pasterskiego zobowiązania do wcielania ideału życia chrześcijańskiego, dawania świadectwa wiernym [Podskalsky $2000,369-270]^{23}$.

Najważniejszym dokumentem powstałym w tym okresie były reguły prowincjalnego synodu włodzimierskiego z 1273 r. Również one zostały wpisane w Nomokanon i były obowiązującym dokumentem prawnym. Potwierdzono w nim obecną już w 34. regule metropolity Jana decyzję o złożeniu z urzędu tych kapłanów, którzy często nadużywają alkoholu, a jednocześnie nie żałując swego postępowania odrzucają sakrament pokuty ${ }^{24}$. Srogie kary wynikały z poziomu moralnego duchowieństwa. A źródło to wystawia nienajlepsze świadectwo ich obyczajom, wspominane są bowiem liczne przypadki zaniedbywania wiernych, zwłaszcza w okresie od niedzieli palmowej do wszystkich świętych, kiedy to księża mieli oddawać się zabawom i pijatykom. Zgodnie z przywołanym przez metropolitę Cyryla III(II) ${ }^{25} 42$. ka-

$21 \mathrm{~W}$ zasadzie 29. czytamy o grzechach wywołanych pijaństwem: „Подобаєт сихъ всєю силою възюраняти єпископомъ, научающи яко пьянству злу царства Божия лишаться, яко пьянство много зла посль̆дуєть [...]" [Іоана 1880, kol. 17].

22 Por. np. Nomokanon z początku XVII w. w zbiorach Biblioteki Narodowej (Akc 2736, mf 15349), k. 379-391.

23 Reguły Cyryla znajdują się we wskazanym w przyp. 22 Nomokanonie na s. 391-396.

24 W 34. regule Jana: „А иже поставлени иєрб̋єве оупиватися имуть, въ отлучениє вложити, да покорившися закону Господню пьянства отлучатъся, аще ли не лишатъся пьянства, изврещи я" [Іоана 1880, kol. 20].

25 Spora część badaczy nadal uważa, że był to drugi metropolita o tym imieniu. Traktują oni jako legendę doniesienia Zachariasza Kopysteńskiego (XVII w.) o pomianniku Soboru św. Sofii w Kijowie, uwzględniającym imię dotąd nie uwzględnianego w rachubach metropolity Cyryla z Grecji (XI w.). 
nonem apostolskim, tacy trwający uporczywie w grzechu jereje, podlegaja karze pozbawienia godności kapłańskiej ${ }^{26}$ :

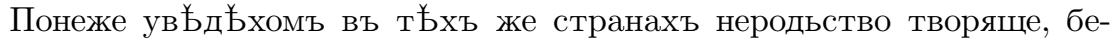
щиньє святительско, оупивающеся безъ мбры въ святыя пречистыя дьни постеныя, от св Бтлъя недбл兮 верьбныя до всбххъ святыхъ, яко не быти божествьному приношению, ни божествьнаго крщения до вс Әхъ святыхъ. Ми же посль̆дьствоуємъ божествьнымъ правиломъ, глаголютъ бо, попъ оупиваяся, да останеться, ли да извержеться. Мы же запов Бдаємъ пре-

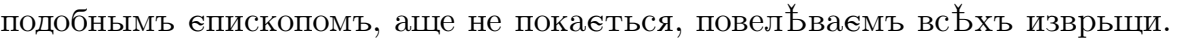
Лоуче бо єдинъ достойныхъ слоужа, неже тысяща беззаконьнъ [Правило Кирила 1880, kol. 97-98].

Problem z pijaccymi mnichami i popami został również uwzględniony w Ustawie kniazia Jarosława, gdzie ustanowiono, że podlegają oni sądowi duchownemu ${ }^{27}$. Kilka stuleci później zasadę usuwania z urzędu krnąbrnych księży odświeżył także metropolita Józef Sołtan. Zgodnie z ustaleniami zwołanego przezeń synodu wileńskiego z 1509 r. pijaństwo jereja było jednym z powodów, dla których można było odebrać mu cerkiew ${ }^{28}$. Reguły wspomnianego hierarchy zostały wydane w $1614 \mathrm{r}$. we Lwowie przez środowisko brackie działające na rzecz odnowy religijnej w metropolii kijowskiej. Niektóre egzemplarze tej broszury zostały doszyte do wydanego w tym samym roku i wydawnictwie Dialogu o kapłaństwie Jana Złotoustego - dzieła ważnego dla przedstawicieli stanu duchownego.

W średniowiecznych pouczeniach kierowanych wyłącznie do duchowieństwa grzechy takie jak nienawiść, gniew czy pijaństwo zostały szeroko omówione. Nauki biskupie docierały do kleru parafialnego głównie dwiema drogami. Były to pouczenia wygłaszane przez władykę w trakcie synodu, lub też zbliżone do nich w treści nauki pokonsekracyjne, które nowo wyświęcony kapłan dostawał w formie pisma okólnego przed odjazdem do wyznaczonej parafii ${ }^{29}$. Pouczenia tworzone dla przedstawicieli stanu du-

26 Kanon Apostolski 42. brzmi: „Biskup, prezbiter lub diakon, który gra w kości i oddaje się pijaństwu, niechaj zaniecha tego procederu albo zostanie złożony z urzędu" [Constitutiones 2007, 282]; [Kanony 2000, 21].

27 Omówienie i różne wersje ustawu por. Я.Н. Щапов [1972, 85-139]. Wspomniana zasada najczęściej występuje w ustawie z nr 35.

28 Metropolita pisał w dokumencie synodalnym, że osoby świeckie nie mogą zabierać cerkwi kapłanom czy ihumenom bez zgody biskupiej i bez udowodnionej w trakcie synodu diecezjalnego winy osoby duchowej. Określone w prawie cerkiewnym powody odebrania świątyni to: zaniedbywanie domu, Służby Bożej i pijaństwo kapłana, którego należy czasowo odsunąć od posługi, a jeśli się nie pokaja, złożyć z urzędu [Солтан 1878, 12-13].

29 Często chirotonia odbywała się w trakcie synodu, nauki te posiadają zbliżoną treść o charakterze dyscyplinarnym i etyczno-moralnym, por. A.Z. Nowak [2014, 185, przyp. 35]. 
chownego zawierały obecne także w niektórych omówionych wcześniej regułach dyscyplinarnych i kazaniach zestawienia ciężkich grzechów, których należało się wystrzegać. W bardzo popularnym przez wiele stuleci trzynastowiecznym synodalnym tekście przypisywanym metropolicie Cyrylowi III(II) czytamy:

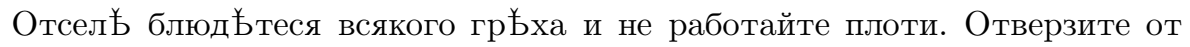
себе пьянство и обьяденье, лишитеся тяжь и сваровъ, вражды, хулы на друга, сквернаго рб̆зоиманья и порукъ, гордости и многорб̆чья, мерзости и ярости, клятвы лжа, скупости, немилосердья зависти и ненависти, льсти и лукавьства [Enископское 1880, kol. 118] ${ }^{30}$.

W tym samym tekście została umieszczona informacja o konieczności złożenia z urzędu tych jerejów, którzy „utopili duszę w grzechach i pijaństwie” [Enuckoncкoe 1880, kol. 115]. Podobnie listy grzechów zawierają teksty pokonsekracyjne, które prawdopodobnie pełniły rolę podręcznego poradnika-informatora dla niedoświadczonych księży. Nazywano je niekiedy chirotoniami i zalecano je wykorzystywać w cotygodniowym rachunku sumienia. $\mathrm{W}$ jednej z takich nauk zestawienie przewinień ujęte zostało $\mathrm{w}$ formę napomnienia kierowanego przez biskupa udzielającego święceń do nowego kapłana:

Nie bądź błaznem, ani figlarzem, ani w mowie nieprzyzwoity, nie bądź pyszny, wyniosły, ni gniewny, ni zapalczywy, ani rozwiązły, bezwstydny, ani pijanica, ani wesołych uczt sam nie inicjuj i innym zabraniaj, nie bądź lichwiarzem i odsetek nie przyjmuj [tłum. A.Z. Nowak] ${ }^{31}$.

W rękopiśmiennych ruskich trebnikach (XV-XVII w.) tę rolę tekstów chirotonii potwierdzają zawarte $\mathrm{w}$ opisie porządku udzielania sakramentu spowiedzi pytania od spowiednika do penitenta oraz tzw. ponowlenija czyli listy grzechów wypowiadane przez czyniącego pokutę. Wersje tych zestawień przeznaczone dla kapłana obfitują w opisy grzechów wywołanych pijaństwem, które często jest ukazywane jako początek pozostałych przewinień i poważnych naruszeń moralności i dyscypliny życia konsekrowanego ${ }^{32}$.

30 Por. także Правило Кирила [1880, 91].

31 „Не боуди кощюньникъ, ни игрець, ни срамословьникъ, ни боуди, ни градъ, ни величавъ, ни гнъъвливъ, ни яръ, ни напраснъ, ни бестоудьнъ, ни пьяница, ни складъ пировыхъ творя, нъ инъмъ възбраняй, ни рб̆зоимбць, накладъ не ємли", [Святительськое 1880, kol. 103-104]; por. także [Поученіе смиренного 1861, 725].

$32 \mathrm{~W}$ pytaniach z artykułu: Вопрос игуменом и сйенноинокомъ z rękop. Trebnika (XVI w.): „Не престоупил ли сшеньства своєго и поученїа сг̃льских и хиротоній или 
Zabytki powstałe w okresie średniowiecza znane były przez stulecia, wpisywano je w Ksiegi Kormcze, Euchologiony, zbiory kaznodziejskie i mieszanego typu (np. Szmaragdy, Złatousty, Torżestwienniki i inne). Szczególnie w składzie Szmaragdu, który był przeznaczony do użytku indywidualnego znajdowało się sporo dydaktycznych nauk, dotyczących zasad zachowania w cerkwi i innych norm, które powinni zachowywać duchowni [Simi 2009, 20-21].

W XVII stuleciu w metropolii kijowskiej niektóre dawne pouczenia doczekały się wersji drukowanych. Przykładowo synodalna nauka przypisywana Cyrylowi III(II) została wydrukowana wielokrotnie: za sprawą biskupa lwowskiego Arseniusza Żeliborskiego osobnym drukiem w 1642 r., oraz w składzie lwowskiego Nomokanonu z 1646 r., a także w Nowogrodzie Siewierskim w 1676 r. z inicjatywy biskupa Łazarza Baranowicza [Запаско, Ісаєвич 1981, nr 297, 351, 529].

W siedemnastowiecznych edycjach Liturgiarionu przed częścią mszalną umieszczano także biblijną listę cnót i grzechów. Lokalizacja nie była przypadkowa zważywszy na fakt, że była to księga, bez której kapłan się nie obywał. Ten popularny także w pasterskich pouczeniach głoszonych przez biskupa do duchowieństwa ${ }^{33}$ fragment dotyczący kapłańskich przymiotów pochodził z pierwszego list św. apostoła Pawła do Tymoteusza. Wersety $(3,1-13)$ dotyczyły m.in. wstrzemięźliwości w jedzeniu i piciu obowiązującej każdego diakona i biskupa, a więc także kapłana, co podkreślali redaktorzy Stużebnika dodając tę informację $\mathrm{w}$ nawiasie ${ }^{34}$. Jak czytamy w liście apostolskim „biskup więc powinien być nienaganny, mąż jednej żony, trzeźwy, rozsądny, przyzwoity, gościnny, sposobny do nauczania, nie przebierający miary w piciu wina, nieskłonny do bicia, ale opanowany, niekłótliwy, niechciwy na grosz, dobrze rządzący własnym domem, trzymający dzieci w uległości, z całą godnością (1 Tym 3,1-4). O diakonach apostoł pisał, że „tak

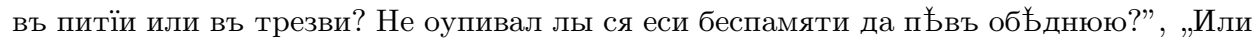

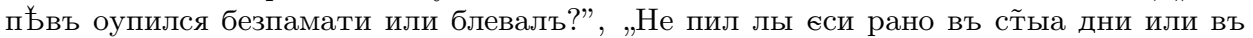
праздникы людми съблажняа?”, „Не оставил ль̆ єси цр̃кви без пь̈нїа пїаньствомъ или небреженїмь". W Trebniku rękop. XV-XVI w. w artykule: Исповпданїє попомъ u дъякономъ: „Не пちл ли єси литоргїи в трезвъ или в питїи”, „Или поздно пил, а заутра служил похмеленъ”, „Не оупивал ли ся єси бес памяти, а на оутріє служил”, „Или служих опился бес памати и блевал и пси полизахомъ”. W tekście Поновленїє свяшенникомъ z Trebnika rękop. XVI w.: „Гд̃не отче обьяденїем и пьянством иж до объда и часов не отпъвъ и многажды во пиръ не званъ ходих и оупився бесчинно валяхся и спах на земли и блевах" [Алмазовъ 1894, s. 181-186, 185-186, 232].

33 Por. np. Йосиф Шумланский [2006, 225].

34 Por. np. Леітургїарїон [1629, 104 (pierwsza numeracja)]; [1639, 164]; [1666, k. 80v]; [1681, k. 92v]; [1691, k. 51v]. 
samo winni być ludzie godni, w mowie nieobłudni, nienadużywający wina, niechciwi brudnego zysku [...]" (1 Tym 3, 8) [Biblia 1995, 1348].

Hierarchowie starali się utrzymać dyscyplinę wśród duchowieństwa również poprzez dobór odpowiednich kandydatów do stanu duchownego. Kościelne dokumenty prawne zwracały uwage na jakości moralne przyszłych kapłanów. Określała je już 34. reguła metropolity Jana ${ }^{35}$, a także $u k a z$ czyli zarządzenie dotyczące wyboru godnych kandydatów, który z czasem pojawił się przed opisem części liturgicznej chirotonii w czynownikach i przyjął formę osobnego artykułu [Неселовскій 1906, 192] ${ }^{36}$. Moralność kandydata była weryfikowana przez wyznaczonego kapłana w miejscu jego zamieszkania, a jeśli odległość na to nie pozwalała, musiał on przedstawić pisemne świadectwa od rodziny i sąsiadów. Odpowiedzialność przyjmował na siebie także spowiednik kandydata [Лотоцький 1931, 61-63]. Pijaństwo znajdowało się na liście grzechów ciężkich, które uniemożliwiają przyjęcie diakońskich i prezbiterskich święceń, jak zostało to określone w pierwszej regule synodalnego dokumentu stworzonego przez metropolitę Cyryla III(II): „[...] nie będzie [kandydat na kapłana] bluźniercą, złodziejem, pijanicą, krzywoprzysięzcą, ani awanturnikiem" 37.

Kijowski Nomokanon z 1629 r. nie uwzględniał pijaństwa w rejestrze grzechów niedopuszczalnych dla kandydatów do święceń duchownych, skupiając się głównie na tych będących pochodną nieczystości [Събранїє 1989, 100-101]. Natomiast pijaństwo otwiera spis tych grzechów w traktacie teologicznym Pokój z Bogiem człowiekowi (Kijów 1669), w którym osobna część została poświęcona grzechom stanu duchownego. Dzieło Innocentego Gizela, podobnie jak nomokanony, mogło mieć charakter normatywny w zakresie prawa kościelnego [Довга 2005, 229]. W nawiązaniu do dwóch fragmentów z listów św. Pawła apostoła: pierwszego do Tymoteusza $(3,1-12)$ i do Tytusa (Tyt 1, 7-9) archimandryta pieczerski pisał o kapłanie: „winien być bez skazy, czyli trzeźwy, nie pijanica, nie zawadiaka, nie kłótliwy, nie samolubny, nie zuchwały, nie swawolny, nie skory do gniewu [...]" [tłum. A.Z. Nowak] ${ }^{38}$.

35 „И єже иерђћмъ до оупиванья пиющимъ иєрђћємъ сице речемъ, яко апостолъ

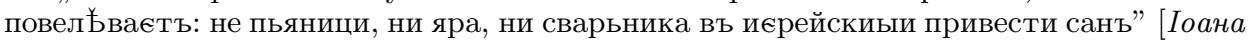
$1880,20]$.

36 Zdaniem tego badacza ukazy pojawiły się najpierw na terenach Rusi południowej [1906, 194, przyp. 50]. Tekst ukazu przedrukowany z tzw. Archijeratykonu (Apxiepamuконъ) z końca XVI w. spisanego dla biskupa Cyryla Terleckiego około 1585-1594 r. dostępny w: [Указ 1932, 137-139].

37 „[...] аще боудоуть не кощюньници, ни хыщници, ни пьяници, ни ротници, ни сварливи" [Правило Кирила 1880, kol. 90-91].

38 „[...] подобаєть єму быти безъ порока, сице: трезвенну, не пїанӥци, не бійци, не сварливу, не себъ угаждающу, не дерзку, не напрасниву, не гнђвливу, но коротку, 
Na fali odrodzenia cerkiewnego w metropolii kijowskiej oprócz pierwszych edycji zabytków średniowiecznych, powstały także nowe nauki dla duchowieństwa, które regulowały sprawy dyscyplinarne i etyczno-moralne. Skoro grzech nieumiarkowania w piciu był w nich omawiany często, to zapewne był to moralny problem, z którym nadal mierzyli się duchowi nauczyciele i reformatorzy.

Świadectwem obyczajów są pouczenia Cyryla Trankwiliona Stawroweckiego z wydanej w 1619 r. w Rachmanowie Ewangelii pouczajacej, który tak opisywał poziom moralny duchowieństwa w pierwszej połowie w. XVII w Pouczeniu o nauczycielach leniwych $i$ upijajacych się: „Оувы нй $\tilde{b}$ зрить око моє въ род占 моємъ, яко болше таковыхъ рабовъ лукавыхъ и вождевъ слђпыхъ, их же пянство неразумїємъ осль̆пило, исъ мертвыми равно положило не одрб̆ но въ геєн兮" [Ставровецкий 1619b, k. 290v]. W pouczeniach dla kapłanów szeroko omawiane są obowiązki duszpasterskie oraz ideał postępowania, który powinien być zgodny z treścią nauczania. Wzór życia, wedle wielokrotnie wyrażonego w naukach przekonania, jest najdoskonalszym sposobem kierownictwa duchowego [Пузина 1931, 93; Тризна 1924, 376], skutecznie wspiera on głoszone przez nauczyciela prawdy, jest czynnikiem ważniejszym niż cuda [Ставровецкий 1619c, k. 309v]. Na tym tle problem księży-pijaków jawił się szczególnie dramatycznie. Stawrowecki przywodził obraz pasterza, który nie głosił Słowa Bożego, a przesiadując w karczmie postępował sprzecznie z jego przesłaniem ${ }^{39}$. Takich jerejów moralista słowami Biblii określił ślepymi przewodnikami dla niewidzących (Mt 15, 14), wieszcząc wieczną zatratę zarówno im, jak i ich podopiecznym:

Точїю спьшшатся къ обяденїю и пянству, въ чревнюю работя. И яковъ пастъръ ихъ, таковы и овца єго, пастыръ безъ бг̃овидёнїя, и разума съвръшеннаго, и наказанїа истинънаго, овца же без св ботлости разумной, въ тм нев Бденїя. Пастыръ спЊшится въ корчемницю, а овца бъжа въ блюдилища, и на позорища сатанинскї, и тако обоим пагуба, пастыру ль̆ности ради, овцам же невъ̆денїа ради, по словеси Ге̃ю, сль̆пець сль̆пца водяй, оба въ яму въпадутъ в бчной погыбели [Ставровецкий 1619d, k. 3].

не завистливу, не сребролюбцу, не скверностяжателну, но страннолюбиву, учителну, Бг̃олюбцу, праведну, воздержателну, и всема чисту. Во єже бы глаголати всякому в дх̃овныя ст̃н古 вдавшемуся. Очистим себе от всякоя скверны плоти и дх̃а, творяще ст̃ню страст兮 Бжиїй" [Гізіел 2009, 216].

39 M. Kuczyńska zauważyła, że Stawrowecki tępił pijaństwo zwłaszcza duchownych i kaznodziejów, właśnie w kontekście zamroczenia umysłu, które to wyklucza przyswajanie wiedzy oraz jej przekazywanie [Kuczyńska 2008, 43]. 
Jak widać z przytoczonego przykładu, grzech osoby duchownej nie był tylko jego osobistą winą, ale niezwykle często powodem grzechu wiernych ${ }^{40}$. Był to według klasyfikacji omówionej przez Piotra Mohyłę, a także Joannicjusza Galatowskiego grzech jawny, który miał skłaniać bliźnich do złego postępowania, dlatego należało za niego „spowiadającym się nakładać wielką epitymie" [Галятовський 1985, 381; Могила 1989, 8]. Duchowny mógł spodziewać się podwójnej kary: najpierw za pijaństwo, lenistwo, wszeteczeństwo i inne ciężkie grzechy, którymi gorszył swoich podopiecznych; a następnie za zaniedbania względem własnej owczarni i ich duchową zgubęet.

Kary Boże dla kapłanów za pijaństwo szczególnie obszernie opisywał Stawrowecki nawiązując do przypowieści o talentach, które nie zostały pomnożone. W jednym z fragmentów pouczenia roztaczał dramatyczną wizję stad rozpraszanych i rozszarpywanych przez drapieżniki w czasie, gdy pasterz oddaje się biesiadom z winem i gęślami:

И предаєшъ овца Хйы волкомъ несытымъ на пожренїє и зв ромъ лютым на растерзанїє пянства ради твоего проклятого. [...] Оуви мнНै подобно речешъ, друг пришелъ къ мнђ и веселихся с нимъ идеже пїютъ вино съ гусльми и свирилми и тогда разыйдоша овца твоя по строминахъ, и падолахъ всякого безаконїа и тамо сутъ пожръты лвами и паки єгда ми

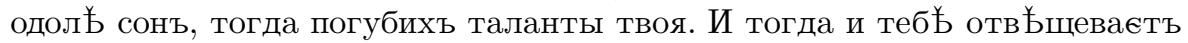

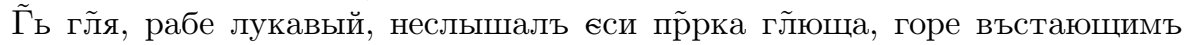
и 3 оутра гонящим пянство и ждущимъ вечера, вино бо пожжетъ ихъ, пїющее съ гусльми и свирилми, а дђ̈лъ гйихъ не творяще, сего ради съгорятъ яко тернїє пламенемъ геенскимъ и не будет мг̃ти моей оугашаяй ихъ [Ставровецкий 1619c, k. 290v].

Stawrowecki przewodników, którzy nie uczą wiernych woli i bojaźni Bożej nazywał zdrajcami, wybierają, bowiem wino i bezczynność, oddają duchowe stada wrogowi bez walki, skazując je tym samym na pewną śmierć:

Азъ бо възищу крови овечъ моих от рукъ вашихъ и за реберъ вашихъ и аггеломъ лютимъ предамъ на мученїе тюхъ. Таковый отв оуслишиши оучителю льћнивый от Бг̃а своего, противу товеего отв Һта. Ты иже нйъ присъдишъ въ блудилищахъ и корчемницахъ оумомъ помраченъ без страха Бж̃іа и нбћкогдаже помышляєшъ о пришествїю Гд̃на своего, и нъже о истязанїю страшномъ, но точїю дйь и нощъ назираєшъ и де

$40,[. .$.$] гріхи священників є не тільки перешкодою для них самих в осягненні Божої$ ласки, але також і для всіх світських людей” [Правила 2010, 308].

41 „Простець бо сгрђшивъ за свою душу єдину отвђть Богу дасть. Іерђй же сгрђшшив, съблазнить многы, и за тъххъ душа отсуженъ будетъ от Бога. Отсель блюдちтеся всякого грђха и не работайте плоти" [Еnuскопское 1880, 118]. 
же вино проливають в корчемницахъ и скорб̋є тоу обрящешися нежели оу олтаря. И не оусугубляєшъ таланта Гйя, но паче погубаєш єго пянства ради твоего, но и от сего зльйшая творишъ, яко и дш̃ъ члг̃скихъ предатель бываєшъ, предаєшъ т бхъ на смерть за не бреженїє твоє и пянство проклятоє. Сего ради сугубую моуку постраждуть таковыи, понеже не научают воли Бж̃ей и страху [Ставровецкий 1619c, k. 290v].

Pomimo że Stawrowecki nie poświęcił duszpasterzom osobnego pouczenia, to jednak problem złych jerejów powraca w wielu tekstach (w podrozdziałach) zbioru i zazwyczaj w kontekście zasadniczego podejmowanego przezeń tematu: odpowiedzialności za głoszenie Słowa Bożego i misję nauczycielską, której realizację uniemożliwia m.in. pijaństwo. Ten wymiar posługi uwydatnił także biskup Józef Szumlański w synodalnej nauce przypominając, że grzechy kapłana są w dwójnasób „,szkodliwe”. Została ona wydana we Lwowie, w składzie dzieła pt. Метрика альбо реєстр, для порядку Церкви Святой и снаднъйшой їнормаиїєй, духовньм свпиким w $1687 \mathrm{r}$. Władyka kierując swoje słowa bezpośrednio do zgromadzonego na soborze duchowieństwa przypominał, że pijany kaznodzieja tracąc władzę rozumu, nie może nauczać innych, a i sam żadnego pożytku nie osiągnie z lektury Pisma św., bowiem alkohol ,zaślepia oczy, wiąże język i czyni umysł zamroczonym":

Давно то повидблъ въ своихъ пов бстехъ мудрый Соломонъ: єслиж челов Һкови простому св Һцкому пїанство єсть такъ шкодливоє и страшгоє, а якожъ не будеть шклдливоє челов Һкови духовному, поневажъ бов Һмъ духовного кождого, иле священника м брскаго, на парохїи зостаючого, єстъ то поприсяженная єго повинност не тылко себе самого, але и парохїанъ своихъ, єсли не щоденне, то принамнђй въ неделю, въ свято урочистоє, в Церквъ Божой в бры и добрыхъ дблл оучити, то треба трезвому быти, бо пїанйй, посполите мовимо, в Һршовъ не складаєтъ. Гдыж само досв Һ̆дченье показуєть, же пїяній не тылко иншого кого, але и себе самого наоучити нбччго з Писма Святаго не может, бо му пїянство оумъ помрачаєтъ, очи осль̆пляєтъ, языкъ вяжетъ, же другїй пїяній слова иле доброго вымовити не можетъ [Шумлянский 2006, 230].

W cytowanym pouczeniu problemowi pijaństwa jerejów biskup poświęcił sporo miejsca (niemal jedna czwarta całej nauki!). Wiązał tę kwestię z powinnościami każdego kapłana, wśród których było nie tylko nauczanie, ale także służba ołtarza, szafowanie sakramentami, dawanie dobrego przykładu.

I tak w kontekście odpowiedniego przygotowania celebransa do Służby Bożej biskup zarysował sugestywny obraz popa-pijaka, który częstokroć 
opuszcza Służbę Bożą lub też, co gorsza, stoi w ołtarzu nie wytrzeźwiawszy. Ten ostatni problem uwypuklił także Dmytro Tuptało w pouczeniu pt. Trzecie przygotowanie do liturgii, dostrzegając poważne konsekwencje tego czynu - zgorszenie wiernych:

И то єсть поприсяженая священника повинност молитися выну, то єстъ найменшого церковнаго набоженъства не опустити, а пїяній муситъ и велико опустити, бо Вечерни, Павечерни не прочитаєть, на Полунощницу нє встанєтъ, Оутрню хочъ то и въ церкви спячи отправитъ, а що найстрашн Бйшая для нецнотливого пїанства, службу Божїю не тылько в повшедный, але и въ недельнїє в и святочнїи дни частокроть опускаєтъ, альбо тєжъ зъ великою неспособностю и пїанстомъ поскверненного т ъ̆ла своєго отправуєтъ [Шумлянский, 2006, 230].

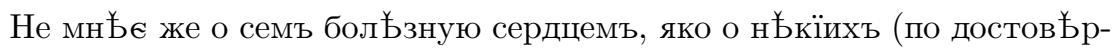
ному намъ доношенїю) слышу, что по вчерашнемъ пьянствованїи, не потрезвившеся, и похмельємъ одержимїи, ни прїуготовльшеся къ служенїю, дерзають лїтургисати, єже людмъ єсть на соблазнъ, а сам Бмъ таковымъ іереомъ на в Һчную погибель [Туптало, 1824, 140].

Ten sposób postępowania przeczył nie tylko porządkowi liturgicznego postu od jadła i napojów, który obowiązywał od wieczora dnia poprzedzającego Służbę, ale i potrzebie czystości każdego celebransa. Dlatego Innocenty Winnicki, który obserwował podobne zachowania wśród księży zwłaszcza w okresie świątecznym, napominał profanujących świętości kapłanów, tradycyjnie przestrzegając ich przed wiecznym potępieniem:

[...] Duchowni podczas Praźników bawiąc na ucztach, mimo swoiey Kapłańskiey vocacij, o trzeźwości zachowania szlubu, tak sobie podpiiaią, że nie tylko do odprawowania nazajutrz Nabożeństwa, ale ani chorych dispositij, incidente Casu, sposobni bydź; owszem podczas ani o sobie pamiętać mogą. Przez co y sami Ciało i Krew Pańska bez należytego przygotowania celebruiąc, na potępienie sobie pożywaią" [Winnicki 1998, 51-52].

Biskup przemyski zauważył, że w nagłym wypadku (incidente Casu) otumaniony alkoholem duchowny nie może służyć pomocą swoim wiernym. To oznacza, że sprowadza na nich duchowe zagrożenie [Winnicki 1998, 52]. Grzech ciężki na sumieniu duszpasterza w przypadku nagłego wezwania do umierającego powodował, że nie mógł on udzielić często nieodzownej dla zbawienia sakramentalnej posługi [Могила 1646, 221]. Józef Szumlański podobnie jak cytowany wyżej Winnicki opisywał ten problem w kontekście pijaństwa kleru i przypominał, że odpowiedzialność za dusze wiernych spoczywa na kapłanie, a zatem to on zostanie ukarany, jeśli doprowadzi do duchowej śmierci chrześcijanina: 
Придасться якїй въ парохїи чїєй на кого наглїй припадокъ, же треба въ ночи, о полночи порватися, всати и пойти, альбо дитя крестити, альбо рождшую, любъ тамъ кого иншого нагле безъгодне оумираючого диспоновати, а свщенникъ на ногахъ не въстоитъ, о собђ не памятаєтъ. Нехай же тамъ кто зъ таковыхъ припадковъ оумретъ въ грђхху смертельномъ без спов Һди, без раздришенїя, а за твоимъ, о їерею, пїанствомъ, в Һдай же, вБдай запевне, же згиненя его зъ рукъ твоихъ от тебе рекв Һровати будутъ, бо самъ Господъ Богъ оу пропока Іезекїиля мовит: Крови же єго от руки твоєя възищу [Шумлянский 2006, 231] ${ }^{42}$.

Kapłan musi zatem żyć w trzeźwości i czystości, a gdyby zdarzyło mu się upić lub popełnić inny haniebny czyn winien niezwłocznie przystąpić do sakramentu pokuty, zanim przystąpi do ołtarza. Unosząc się sprawiedliwym gniewem Jozafat Kuncewicz napominał celebransów w Konstytucjach i zasadach dla kapłanów: „W imię Boga Żywego [...] niechaj nie waży się z obciążonym sumieniem i bez św. spowiedzi odprawiać liturgii" ${ }^{43}$.

Powyższe przykłady przekonują, że większość moralistów w napomnieniach do duchowieństwa apelując do sumień, jednocześnie straszyła karą z niebios. Już metropolia Jan II w regułach zobowiązywał biskupów do głoszenia tej prawdy, iż pijacy nie dostępują królestwa niebieskiego [Іоана 1880, kol. 17]. Szumlański przypominał jerejom, że są zwykłymi śmiertelnikami i jeśli śmierć zastanie ich na pijaństwie zostaną za nie osądzeni [Шумлянский 2006, 231]. Nieco mocniejsze argumenty lękowe występowały w kazaniach Trankwiliona. Moralista także wspominał konieczność rozliczenia się przy końcu czasów z talentów, które zostały powierzone duszpasterzom. Jednocześnie w sposób emocjonalny budował pełne grozy i utrzymane w nieco apokaliptycznym tonie obrazy męki piekielnej dla tych którzy zaprzepaścili Boże dary ${ }^{44}$.

$42 \mathrm{~W}$ trzynastowiecznej nauce na ten temat napisano: „Боуди сторожь день и ночь съ кршениємъ и съ покаяниємъ, и съ причащениємь и твори достойное правило съ любовью, тихо, не бързяйся.... Аще ли кого изгубишь ль̆ностью и неродством мука ихъ на тобђ възискома боудетъ" [Святительськое 1880, kol. 107-108].

43 „В ім'я Бога Живого, заклинаємо всіх наших священників жити в тверезості й чистоті. Коли б вони були свідомі яких-небудь тяжких своїх гріхів, тобто якщо привелося їм упитись або в чомусь іншому провинитися, треба їм тоді якнайскоріше приступити до Святої Сповіді, і нехай вони не наважуться з обтяженим сумлінням, без Святої Сповіді, відправляти Літургію або інші Богослужіння" [Правила 2010, 308].

44 Por. np. „Оуслышћте оубо гласъ сей страшный, и прещенїє грозное о оучитель

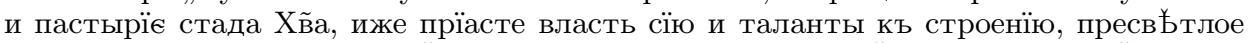

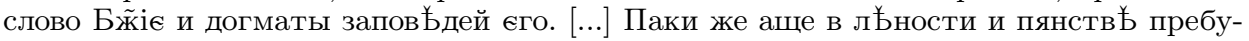
дешъ и нерадити о овцахъ Хйыхъ начнешъ, тогда осудишися и къ моукамъ геенскимъ отсланъ будеши, съ онымъ лукавымъ и льнивымъ рабомъ. Аще бо онъ изгонимъ вонъ от дому Гйя, иже не имъя одъанїа брачного, тыже что речеши, иже съкриваєшъ в землю талантъ Бжійи", [...] Оувы мн古 коликую зато постраждешъ моуку, 
Prawda o katastrofalnym wpływie pijaństwa na życie i godność człowieka nie podlega przedawnieniu, bowiem skutki nadużywania alkoholu są pomimo zmian cywilizacyjno-kulturalnych te same. Zmienia się natomiast społeczny stosunek i oczekiwanie dotyczące dopuszczalnych i karygodnych zachowań. Liczne nauki poświęcone w całości lub choćby we fragmencie temu problemowi świadczą w pewnym stopniu o dość powszechnym problemie z pijaństwem. Jednocześnie ich spora frekwencja wynika właśnie ze specyfiki samego stanu upojenia i wywoływanego przezeń niebezpieczeństwa. Właściwie nie ma takiego grzechu, który nie mógłby być pochodną opilstwa, co starali się uwypuklić moraliści na przestrzeni wieków. Gizel twierdził, że skłania ono do złego postępowania bardziej niż inne grzechy, człowiek pijany jest w stanie zrobić to, o czym na trzeźwo wstydzi się myśleć ${ }^{45}$. Poprzez upojenie człowiek sprowadza fizyczne i duchowe niebezpieczeństwo na siebie i otoczenie. Zapewne dlatego ojciec Innocenty w traktacie pisał o pijaństwie, że jest to grzech najbliższy wiecznej zatracie. W przypadku wszystkich śmiertelnych grzechów skrucha jest szansą na ratunek w chwili zagrożenia śmiercią, dla człowieka w stanie upojenia nie jest ona dostępna, choć właśnie wówczas, co dostrzegał także Szumlański, znajduje się on w sytuacjach, które sprzyjają nagłej śmierci ${ }^{46}$ :

Сей же грб̆хъ пїанства, найближшїй єст погибели в

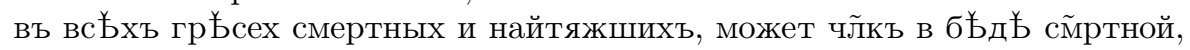

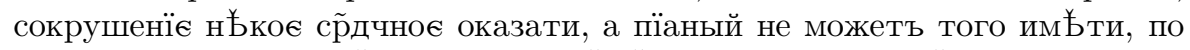
аки бездушный, разв и въ адち возведетъ очи свой сый в мукахъ. А кромђ иныхъ бъ смертныйх, и от самаго пїанства, мнози внезапу оумирают тб̆ломъ и дш̃ею въ в Һ̌ки, оупившис или тонут или шіи себъ ламають [Гізіел 2009, 156].

Pijaństwo osób duchownych jest szczególnie rażące, oczy parafian są zwrócone na kapłana, a ten który winien być wzorem postępowania, tracąc rozum, odróżniający go od pozostałych stworzeń, upodabnia się do zwierzęcia. Nawet jeśli pijaństwu nie towarzyszy inny grzech, to i tak kapłan zamroczony alkoholem popełnia bardzo ciężki grzech, ponieważ niszczy w sobie

аще бо не сътворшій мл̃ти требующимъ, ошуюю поставляются и въ огонь гаєнскїй посылаются моучити. Тыже что за отв бть тогда даси судїи страшному и правосудному, єгда тя стяжет о таланты сребра своего и въпросить о овцахъ погибшихь" [Ставровецкий 1619b, k. 290].

45 „И аще в иных грђ̋ceх, похоть злая влекущая чл̃ка на зло, разумъ єму помрачаєтъ, то колми паче в пїанств Бै, єже кровъ в чл̃вц и на вся злая, дђла тмы, творит оудобнымъ и дерзкимъ, яко чесого по трезву и воспомянути кто стыдится, на сіє по аїану доброхотнъ оустремляєтся" [Гізіел 2009, 156]. 46 „Пїянство здоровя челов Һкови оуймуєтъ, о припадки розмаитїи и о наглую смертб частокротне приправуєтъ” [Шумлянский 2006, 230]. 
Boży obraz ${ }^{47}$. Moraliści próbowali odstręczyć od pijaństwa zarówno pasterzy jak i wiernych nie tylko strasząc karą wieczną, ale i opisując fizjologiczne szczegóły ciała człowieczego poddanego zbyt dużej ilości alkoholu. Zdaniem Stawroweckiego człowiek upojony jest odrażający i nie różni się swoim zachowaniem i wyglądem od szaleńca: podobnie jak on rzuca się o ziemię, toczy pianę, wybałusza oczy i zgrzyta zębami. Autor pouczenia porównał pijanice do psa, co w odczuciu odbiorcy siedemnastowiecznego było bardzo dosadne i mogło uchodzić za obraźliwe [Яковенко 2002, 141-143].

Въпросиль быхъ назъ нҺкоихъ, чимъ разнъствуєтъ бъсноватого пя-

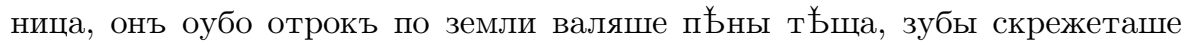
оцепенъваа, но что разнъствуєтъ сего пяница, нетаажде ли творятъ, бЊс обжирства тһ̆ми, ибо сей егдася обжыретъ, тогда и зубами скрежетъ,

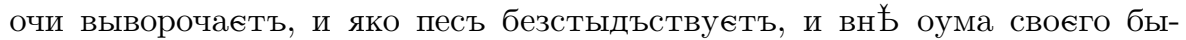
ваєтъ, иногдыже бъсъ обжирства и по земли валяєть єго, яко всђмъ вц Ғломоудрї живоущимъ отвращатися от єго злонравїа: такожде и прочїи зло творъцы тожде лоукавыи духъ имуще внђ оум своего бываютъ, и духъ грђховного въждельннїа в нихъ дちйствуєтъ, и гонитъ ихъ и въмћтаєть въ огонь желанї грђховныхъ, и въ воду смущенїа и невђріа, и обуревані почихъ страстей грђхховныхъ и всђ таковый лютђйшая страждутъ от онаго лунатика [Ставровецкий 1619d, k. 56v].

Sugestywny, choć nieco bardziej stonowany opis wyglądu wystawiającego się na pośmiewisko wiernych kapłana - pijaka: nikczemnej postawy, brudnego, z rozwichrzonym włosem i w rozchełstanej sukmanie; znajduje się w nauce synodalnej Szumlańskiego [Шумлянский 2006, 229].

Moraliści na przestrzeni kilku stuleci poświęcili problemowi pijaństwa sporo uwagi. Bez względu na epokę piętnowano ten grzech, zgodnie podkreślając, że jest niezwykle niebezpiecznym źródłem innych ciężkich przewinień. Grzech szczególnie często omawiany był w kontekście posługi duchowej grzesznego kapłana. Zwłaszcza nauczyciele z czasów odrodzenia cerkiewnego z początku wieku XVII często wskazywali na sprzeczność, która istnieje między ideałem chrześcijańskiego kapłaństwa oraz potrzebą dawania świadectwa prawdy życiem i słowem, a nadużywaniem alkoholu, które jest ich jawnym zaprzeczeniem, gdyż degraduje moralnie, wiedzie do ośmieszenia, często jest powodem zgorszenia, a nawet grzechu wiernych. Nowością w drukowanych źródłach z tego okresu jest o wiele mocniejsze powiązanie problemu opilstwa z konkretnymi zaniedbaniami jereja jako celebransa,

47 „[...] єда ли то само нъст вельй гръх? Погубляти образъ Бжїій, сіестъ Рузумъ, им же Бг̃ъ чл̃ка надъ вся созданїя оукрасилъ и быти злообразнНйшимъ надъ скоты нечистыя" [Гізіел 2009, 156]. 
szafarza sakramentów, a zwłaszcza sługi słowa i nauczyciela. Było to z pewnością mocno związane z dążeniem ówczesnych reformatorów do odbudowy formacji kapłańskiej.

\section{Źródła}

\section{Druki}

Biblia Tysiaclecia, 1995, wydanie trzecie poprawione, Poznań-Warszawa.

Constitutiones Apostolorum. Konstytucje apostolskie oraz Kanony Pamfilosa z apostolskiego synodu w Antiochii, Prawo kanoniczne świętych Apostołów, Kary świętych Apostołów dla upadtych, Euchologion Serapiona, 2007, t. 2: Synody $i$ kolekcje praw, tłum. S. Kalinkowski, A. Caba, oprac. A. Baron, H. Pietras, Kraków.

Kanony Kościoła prawostawnego, 2000, tłum. A. Znosko, Hajnówka.

Klimak Jan, 2011, Drabina raju, tłum. W. Polanowski, E. Osęk (Do pasterza), przedmowa M. Starowieyski, wstęp A. Jasiewicz, Kęty.

Patrologia Graeca, ed. J.P. Migne, vol. 88, kol. 869 D.

Winnicki Innocenty, 1998, Ustawy Rzadu Duchownego in ritu graeco unito Dioesii przemyskiey na congregacij soborney uchwalone (Kraków 1694), [w:] Ustawy rzadu duchowego i inne pisma, przedmowa Stanisława Stępnia, Przemyśl.

Галятовський Іоаникій, 1985, Грпхи розмаитӥи, вократип написанньее, до сповпдника и до сповпдаючагося належатъ, жебь до сповпди готуючися книжку тую читалъ и впдалъ, якихъ маєтъ грпговъ сповпдатися и жебы сповпдник(ъ), тую книжку читаючи впдалъ, якихъ его маєтъ на сповпди слухати грпговъ и од нихъ разрпшити (Чернтгпв 1685), [w:] Ключ розуміння, орrac. І.П. Чепіга, Київ.

Гізіел Иннокентїй, Миръ з Бг̃омъ чл̃вюку или Покаянїє Сп̃оє (Киевъ 1669), [w:] Іннокентій Гізелъ, Вибрані твори у 3 томах, т. 1, кн. 2: fotokopia oryginału, Київ-Львів 2009.

Гізіел Иннокентій, 2012, Наука о Тайнп Сг̃ Покаянїя тоєстъ о правдивой и Сакраменталной исповпди. Придав сут к тому и Лпкарства на грпхи и Выводы о пожитку частой исповпди (Киевъ 1671), [przedruk w:] Іннокентій Гізель, Вибрані твори у 3 томах, т. 1, кн. 1, Київ-Львів.

Голенковский Варлаам, 1714, Предословїе от слова Іоана Златоустаго къ читателю блггочестивому дговоному, [w:] Діалогисм дгохоный си єст двоєсловїє внемъ же беспдуєтъ любитель со любовїю о іереєх добрых и зльх и о Таинь Свхаристїи Стпой и о плодах єя в ползу дхповньмъ и мірскимъ, Киевъ. 
Епископское поученіе собору епархіальнаго духовенства, 1880, [w:] Русская Историческая Библіотека, t. 6: Памятники древне-русскаго каноническаго права, ч. 1: Памятники XI-XV в., nr 8, Санкт Петербургъ.

Золоте слово. Хрестоматія літератури Украӥни - Русі епохи середньовіччя IX-XV столітmя, 2002b, т. 2, ред. В. Яременка.

Иже въ стпьхъ Ойя нашего Іоанна Златоустаго Архїєи̃па Константінополя книга о согщенъствп къ неиже въ кратцп събранноє житїе Ст̃го u прочая ноужнаа в общую ползу простимъ паче же блговпннымъ іереомъ въ исправленїе приложена суотъ, 1614, Лвовъ.

Іоанн Златоуст, 2002, Напучения священникам, [w:] Золоте слово. Хрестоматія літератури України - Русі епохи середньовіччя IX-XV столітmя, т. 1, ред. В. Яременка, Київ.

Іоана, митрополита рускаго, нереченаго пророкомъ Христовьлъ, написавшаго правила черковная отъ святьхъ книгъ въ кратцп Якову черноризьцю, 1880, [w:] Русская Историческая Библіотека, т. 6: Памятники древне-русскаго каноническаго права, ч. 1: Памятники XI-XV в., $\mathrm{nr} 1$, Санкт Петербургъ.

Кипріан Митр., 1861, Посльсловіе (Изъ Служебника), [w:] Ф. Буслаєв, Историческая хрестоматия древнерусской черковно-учительной литератуpbl, Москва.

Леітургїарїон си єстъ служебникъ, 1629, Киевъ (pierwsza numeracja).

Леітургіаріон си єстъ Служебникъ, 1639, Киевъ.

Леітургіаріон си єстъ служебникъ, 1666, Лвовъ.

Леітургіаріон си єстъ служебникъ, 1681, Лвовъ.

Леітургіаріон си єстъ служебникъ, 1691, Лвовъ.

Наука о се(д)ми тайнахъ и(е)рковныл(х). Пре(з)витеромъ до прыстойного шафованя тайнами с(вя)тыми барзо потребная, ok. 1617/1618, Вілно.

О казняхъ Божіихъ, 1973, [w:] Я. Левицький, Перші українські проповідники i $\ddot{x}$ твори, Рим.

Могила Петро, О правилномъ или законном служители [...] Бжгттвенныя Тайнь Трла и Крве Гг̃ней, и о єжн како подобаетъ сему предъ оуготовляти себе къ достойному служенїю Бжтввенныя Литургїя, и Причашенїю Бжтпвенныхъ Хёьхъ Таинъ, [w:] Еухологіон албо молитословъ или требникъ, ч. 1, Киевъ 1646.

Могила Петро, 1989, Преосиеннним Архіеп̃пом, Митрополитом, Бг̃олюбезнпйшим Єп̃пом, и вспмъ Дг̃овникомъ от Бг̃а Властїю Архїерейскою Осииеннымъ. Предъсловїе на Номоканон (Киев 1629), fotokopia Noтоkanonu [w:] Opera facultatis theologicae (Universitas Catholica Ucrainorum S. Clementis Papae), fascimile O. Horbatsch curavit, Romae.

Могила Петро, 1898, Събранїє Короткой Науки. О Артикулахъ Bпры православнокатолической Хрїстӥянской ведлуг вызнаня и Науки Церквє Ст. Восточнои Соборной Апостолской (Київ 1645), [w:] С. Голубев, 
Кіевскій: митрополитъ Петръ Могила и его сподвижники, т. 2 (Приложенія), dok. LXXXI, Кіевъ.

Повчання Мойсея, ігумена новогродского, про надмірну пиятику, 2002, [w:] Золоте слово. Хрестоматія літератури України - Русі епохи середньовіччя $I X-X V$ століття, т. 2, ред. В. Яременка, Київ.

Повчання мудрого епископа білогородьского Григорія, 2002a, [w:] Золоте слово. Хрестоматія літератури України - Русі епохи середньовіччя IX-XV столітmя, т. 2, ред. В. Яременка, Київ.

Поученіе смиренного Петра митрополита Кіевскаго и всея Руси къ епископомъ, и попомъ, и архімандритом, и игуменом и дьяконом, и ко мнихом, и ко вспм православныл крестьаном, 1862, [w:] Памятники старинной русской литературь, вид. Г. Кушелевый-Безбородко, ч. 4, ред. Н. Костомаров, Санкт Петербургъ.

Поученіе смиренного Петра митрополита Кіевскаго и всея Руси игуменомъ, попомъ и діякономъ, 1861, [w:] Ф. Буслаєв, Историческая хрестоматия древнерусской иерковно-учительной литературы, Москва.

Правила і конституиіі написані святим Йосафатом для свої священників, 2010, [w:] Святий Йосафат Кунцевич. Документи щодо беатифікації, переклад Й. Романик, Жовква.

Правило Кирила, митрополита роускаго (Опредпленія владимірскаго собора 1274 г.), 1880, [w:] Русская Историческая Библіотека, t. 6: Памятники древне-русскаго каноническаго права, сz. 1: Памятники XI-XV в., Санкт Петербургъ.

Пузина А., Синод ведле звичаю дорочного, [w:] I. Огієнко, Загублений кремянецький стародрук: «Синод лущький» 1638 р., nadbitka z czasopisma „Елпіс" V, Варшава 1931.

Про кари Божії, 2002, [w:] Золоте слово. Хрестоматія літератури України - Русі епохи середньовіччя IX-XV столітmя, т. 1, ред. В. Яременка, Київ.

Солтан Іосифь, 1878, Соборъ, во спасаемомъ градп Вільни бьвиій, [w:] Русская Историческая Библіотека, т. 4: Памятники полемической литературьл въ Западной Руси, ч. 1, Санктпетербургъ.

Святительськое поученіе новопоставленному священнику, 1880, [w:] Русская Историческая Библіотека, т. 6: Памятники древне-русскаго каноническаго права, ч. 1: Памятники XI-XV в., nr 7, Санктпетербургъ.

Събранїє от различньхъ Правилъ, о еже, кая съгрпшенїа возьраняют бити сииннику (Номоканон си естъ Законоправилникъ Киев 1629), 1989, [w:] Opera facultatis theologicae (Universitas Catholica Ucrainorum S. Clementis Papae), fascimile O. Horbatsch curavit, Romae.

Ставровецкий Кирилл Транквилїон, 1619a, Поученїе в нг̃ ю 4. Ст̃го Поста. Часть 2. о постп и млттвп, яко се єстъ велїє оружї на дїавола, и о оупивающихъся яко нпмало разнь бтсноватого, [w:] Свангеліе Учителноє албо казаня на ндляя през рокъ и на праздники Гп̃дкїе и нарочитылм ст̃пьмъ оугодником Бгісіим, Рохмановъ, сz. 1, k. 56v. 
Ставровецкий Кирилл Транквилїон, 1619b, Поученїе в неделю 16, [w:] Євангелїе Учителноє.., сz. 1, k. 290.

Ставровецкий Кирилл Транквилїон, 1619с, Поученїе в неделю 20, [w:] Євангелїе Учителноє..., cz. 1, k. 309v.

Ставровецкий Кирилл Транквилїон, 1619d, Въ началь индикта сирпчъ новаго лтта поученїе пръвое, [w:] Свангелїе Учителноє..., сz. 2, k. 3.

Тризна Іосифъ, 1924, До чителника духовного (Требникъ сирпчъ Мл̃товникъ импяй в себп Цргковная послпдованїя Іереемъ подобаюшїя Київ 1652), [w:] Хв. Тітов, Матеріяли для історії книжної справи на Вкраїні в XVI-XVIII в.в. Всезбірка передмов до українських стародруків, Київ.

[Туптало] Димитрїй Митрополитъ, 1824, Третїе прїуготовленїе [Іереовъ къ Бжественному причащенїю], [w:] Сочиненїя Святого Дмитрїя митрополита Ростовскаго, t. 1: Содержаща въ себп разныл неболшыя сего Святителя творенїя, съ присовокупленїемъ житїя его и келейныхъ записокъ, Киев.

Указ како подобаєт избрати годных на священство. I ставити оу іерейскій, и дїаконьскьй чинъ, 1932, [w:] О. Лотоцький, Украӥнський Архієратикон, „ЕАПІ $”$ VI, z. 1-2.

Шумланский Йосиф, 2006, Нравоученїе от насъ Eпископа вамъ мїрскимъ іереомъ, [przedruk w:] I. Скочилас, Собори Львівської епархії XVIXVIII століть, Львів.

\section{Rękopis}

Номоканон (XVII w.), Biblioteka Narodowa Akc 2736 (mf 15349)

\section{Literatura}

Delumeau J., 1994, Grzech i strach. Poczucie winy w kulturze Zachodu XIIIXVIII w., tłum. A. Szymanowski, Warszawa.

Derdziuk A., 1996, Grzech w XVIII w. Nurty w polskiej teologii moralnej, Lublin.

Kuczyńska M., 2008, Teologia moralna - zakres tematyczny i formy istnienia w postyllografii ruskiej (na materiale Ewangelii Pouczajacej Cyryla Stawrowieckiego), „Київська Академія” 6, s. 37-47.

Jasiewicz A., 2011, Wstęp (Wptyw dzieła na świat stowiański), [w:] Św. Jan Klimak, Drabina raju, Kęty 2011, s. 19-86.

Nowak A.Z., 2014, Synodalne źródła nauk dla kapłanów w metropolii kijowskiej do XVII w., „Latopisy Akademii Supraskiej” 5, M. Kuczyńska, U. Pawluczuk (red.), s. 181-194.

Podskalsky G., 2000, Chrześcijaństwo i literatura teologiczna na Rusi Kijowskiej (988-1237), Kraków. 
Simi S., 2009, Слова и поучения против язычества в восточнословянской рукописной традиции и рукописи Pio Slavo 26, [w:] Krakowsko-wileńskie studia slawistyczne, t. 4, pod redakcją M. Kuczyńskiej, W. Stępniak-Minczewej, J. Stradomskiego, Kraków, s. 7-35.

Špidlik T., 2005, Duchowość chrześcijańskiego Wschodu. Przewodnik systematyczny, Kraków.

Thomson F.J., 1999, The Nature of the Reception of Christian Byzantine Culture in Russia $i$ the Tenth to the Thirteen Centuries and its Implications for Russian Culture, [w:] The Reception of Byzantine Culture in Mediaeval Russia, Aldershot-Brookfield USA-Singapore-Sydney, s. 107-139 (przedruk z zachowaniem numeracji stron z „Slavica Gandensia” 5, 1978.

Алмазовъ А., Тайная исповпдь въ Православной Восточной Церкви: Опьт внпшней исторіu, t. 3: Приложенія, Одесса 1894.

Довга Л., 2005, Соціальна утопія Інокентія Гізеля, [w:] Україна XVII ст.: суспільство, філософія, культура, ред. Л. Довга, Н. Яковенко, Київ, s. $227-266$.

Запаско Я., Ісаєвич Я., 1981, Пам'ятки книжкового мистецтва. Каталог стародруків виданих на Україні, t. 1, Львів.

Кириличні рукописні книги у фондах Львівскої наукової бібліотеки ім. В. Стефаника НАН України. Каталог, 2007, t. 1: XI-XVI ст., oprac. i gł. red. М.М. Кольбух, Львів.

Корзо М.А., 2010, „Мир з Богом чоловіку” Інокентія Гізеля у контексті католииької моральної теологіӥ кінчя XVI - першої половини XVII cm., [w:] Іннокентій Гізель, Вибрані твори у 3 томах, t. 3, Київ-Львів, s. $195-262$.

Корзо М.А., 2014, О некоторых изданиях киевской митрополии в рукописном наследии Евфимия Чудовского, „Славяноведение” 2.

Лотоцький О., 1931, Українськи джерела иерковного права, Варшава.

Неселовскій А., 1906, Чинь хиротесій и хиротоній, Камянецъ-Подольскъ.

Перекладна література. Ораторско-учителна проза, 2014, [w:] Iсторія украӥнської літератури, т. 1, ред. Ю. Пелешенко, М. Сулима, Київ, s. 173-194.

ПЪ̆тухов Е., Серапіонъ Владимирскій, Русскій проповпдникъ XIII впка, Санкт Петербургъ 1888.

Смирнов С.И., 1898, Приложение 2 ктатье «Древнерусский духовник», „Богословский вестник", t. 4, nr 10, s. 2-4.

Срезневский И.И., 1893, hasło: блудъ, [w:] Матеріаль для словаря древне-русскаго языка по письменнымъ памятникамъ, т. 1: А-К, Санктпетербургъ.

Щапов Я.Н., 1976, Восточнославянские и южнославянские рукописные книги в собраниях Польской Народной Республики, ч. 1: Рукописи собраний Варшавь и Кракова (№№ 1-93), Москва. 
Щапов Я.Н., 1972, Княжеские уставы и иерковь в Древней Руси XI-XIV вв., Москва.

Яковенко Н., 2002, Паралельний світ. Дослідження з історії уявлень та ідей в Украӥні XVI-XVII ст., Київ.

\section{THE SIN OF DRUNKENNESS IN THE RUTHENIAN TEACHINGS OF THE PRIESTS (KYIV METROPOLITANATE OF $11^{\text {th }}-$ THE BEGINNING $18^{\text {th }}$ CENTURY)}

\section{S U M M A R Y}

Moralists over several centuries devoted much attention to the problem of binge drinking. Regardless of age condemning this sin, commonly emphasizing as extremely dangerous source of other serious blames. The sin was particularly discussed in the context of the spiritual ministry of sinful priest. Especially teachers from the revival of the Orthodox times of early $17^{\text {th }}$ century, often used to point out the contradiction, that exists between the ideal of the Christian priesthood and the need to bear witness to the truth of life and words and abuse of alcohol, which is its explicit denial, degrades morally, leads to ridicule and is the reason for scandal and even sin faithful. New to the printed sources from this period, is much stronger link with the specific problem of drunkenness and negligence of priest as celebrant, minister of the sacraments, especially the servant of the words and the teacher. It was connected with the then desire to rebuild priestly formation. 